\title{
Ultrasound-assisted green synthesis of pyrroles and pyridazines in water via three-component condensation reactions of arylglyoxals
}

\author{
Bagher Eftekhari-Sis ${ }^{*}$ and Saleh Vahdati-Khajeh
}

Department of Chemistry, University of Maragheh, P. O. Box. 55181-83111, Maragheh, Iran

\begin{tabular}{l}
\hline C H R O N I C L E \\
\hline Article history: \\
Received October 25, 2012 \\
Received in Revised form \\
December 6, 2012 \\
Accepted 22 February 2013 \\
Available online \\
23 February 2013 \\
\hline Keywords: \\
Pyrroles \\
Pyridazines \\
Ultrasound \\
Multi-component reactions \\
Green chemistry
\end{tabular}

A B S T R A C T
A green and efficient method for the preparation of 5-aryl-4-hydroxy-2-methyl-1 $H$-pyrrole-3- carboxylic acid esters and 6-aryl-3-methylpyridazine-4-carboxylic acid esters via three- component reaction of arylglyoxal hydrates with $\beta$-dicarbonyl compounds in the presence of ammonium acetate and hydrazine hydrate using water as solvent under ultrasonic irradiation was reported. The reactions proceeded rapidly and afforded the corresponding pyrroles and pyridazines in good to high yields in very short reaction time.

\section{Introduction}

Condensation reactions of arylglyoxals, aromatic $\alpha$-keto aldehydes, containing both aldehyde and ketone functional groups with different reactivity, play an important role in organic synthesis especially in synthesis of heterocyclic compounds ${ }^{1}$. Pyrroles are one of the most important heterocycles that broadly found in natural products ${ }^{2}$, pharmaceuticals ${ }^{3}$ and bioactive molecules ${ }^{4}$ and also used in material science ${ }^{5}$. Many methods have been developed for pyrrole synthesis ${ }^{6}$, which include Knorr, Paal-Knorr, and Hantzsch syntheses and 1,3-dipolar cycloaddition reactions. Additionally, pyridazine ring is broadly present in biologically ${ }^{7}$ and pharmacologically active compounds $^{8}$ such as anti-depressants. Pyridazines are also of considerable interest because of their

* Corresponding author.

E-mail addresses: eftekharisis@maragheh.ac.ir(B. Eftekhari-Sis)

C) 2013 Growing Science Ltd. All rights reserved.

doi: $10.5267 /$ j.ccl.2013.02.002 
synthetic utility ${ }^{9}$ and applications in physical organic chemistry ${ }^{10}$. A number of pyridazines syntheses have been previously reported in the literature ${ }^{11}$.

There are many published comprehensive books ${ }^{12}$ and papers ${ }^{13}$ indicate chemical application of ultrasound irradiation in organic chemistry, which offers an efficient and facile route for a large variety of syntheses. So, a large number of organic reactions ${ }^{14}$ and synthesis of pyrroles and pyridazines ${ }^{15}$ were reported under ultrasound (US) irradiation. Despite the large number of reports on the construction of pyrrole and pyridazine heterocycles are available in the literature, due to the importance of these heterocycles in medicinal and material chemistry, development of new routes, which lead to these heterocycles in higher yields, shorter reaction time or milder conditions could receive considerable attention in organic synthesis. In continuation of our works ${ }^{16}$, herein, we wish to report an efficient and facile procedure for the synthesis of pyrrole 3 and pyridazine $\mathbf{4}$ heterocycles by the reaction of various substituted phenylglyoxal hydrates $\mathbf{1}$ and $\beta$-dicarbonyl compounds 2 in the presence of ammonium acetate and hydrazine hydrate under US irradiation, respectively (Scheme 1).

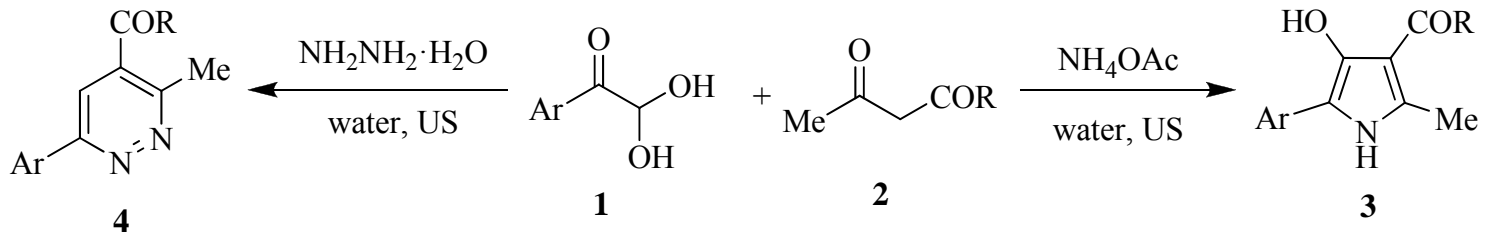

Scheme 1. US-promoted synthesis of pyrroles 3 and pyridazines 4

\section{Results and Discussion}

Arylglyoxals hydrates 1 were prepared by oxidation of acetophenones using $\mathrm{SeO}_{2}$ in refluxing dioxane in the presence of water as Riley and co-worker's report ${ }^{17}$. Arylglyoxals 1 were transformed into the corresponding pyrroles $\mathbf{3}$ by sonification of a mixture of $\mathbf{1}$ with $\beta$-dicarbonyl compound $\mathbf{2}$ in water in the presence of an excess amount of $\mathrm{NH}_{4} \mathrm{OAc}$. The reactions were monitored by TLC. After completion of the reaction, the solid product was isolated by simple filtration. The products were obtained in high yields in a short reaction time. The color changes of the reaction mixture during the reaction of acetylacetone, phenylglyoxal hydrate and $\mathrm{NH}_{4} \mathrm{OAc}$ in water are indicated in Fig. 1.

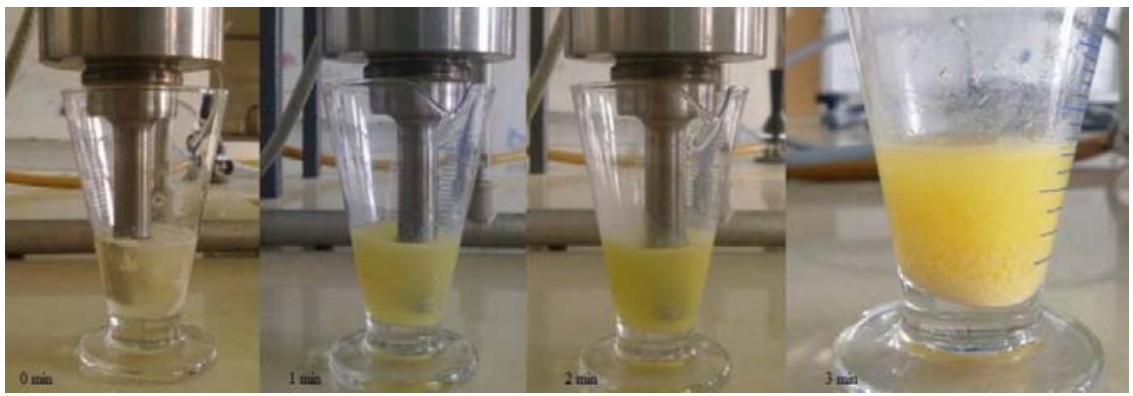

Fig. 1. Gestures of color changes of the reaction mixture during the reaction

The gray colored suspension, resulting from non-dissolving of starting materials in water, was changed to yellow after $1 \mathrm{~min}$ and the reaction was finished along with appearance of the white solid in about $3 \mathrm{~min}$. In the previous report, ${ }^{6 \mathrm{~g}}$ in addition to desired pyrrole 3, corresponding 3-aroyl-4(5)arylimidazols were produced as by-products via cyclo-condensation of two molecules of arylglyoxals with $\mathrm{NH}_{4} \mathrm{OAc}$, while in the presence of ultrasound irradiation, pyrroles 3 were obtained as sole products. The yields and the structure of obtained pyrroles 3 are illustrated in Table 1. All known compounds 3a-g were characterized by their ${ }^{1} \mathrm{H}$ NMR spectra and compared with those reported in the literature. The unknown 4-nitrophenyl substituted pyrroles $\mathbf{3 h}-\mathbf{k}$, were characterized by FT-IR, ${ }^{1} \mathrm{H}$ NMR and ${ }^{13} \mathrm{C}$ NMR techniques. 
Table 1. Synthesis of 3-hydroxy pyrroles 3 (see also Scheme 1)

\begin{tabular}{|c|c|c|c|c|c|c|}
\hline Entry & Ar & $\mathbf{R}$ & Pyrrole 3 & & Mp [reported Mp] $\left({ }^{\circ} \mathrm{C}\right)$ & Yield (\%) $^{\mathrm{a}}$ \\
\hline 1 & $\mathrm{C}_{6} \mathrm{H}_{5}$ & $\mathrm{Me}$ & & 3a & dec. $194[\text { dec. } 236]^{6 \mathrm{~g}}$ & 90 \\
\hline 2 & $\mathrm{C}_{6} \mathrm{H}_{5}$ & $\mathrm{OMe}$ & & $3 b$ & dec. $181[\text { dec. } 233]^{6 \mathrm{~g}}$ & 91 \\
\hline 3 & $\mathrm{C}_{6} \mathrm{H}_{5}$ & OEt & & 3c & dec. $190[\text { dec. } 232]^{6 \mathrm{~g}}$ & 85 \\
\hline 4 & 4- $\mathrm{ClC}_{6} \mathrm{H}_{4}$ & $\mathrm{Me}$ & & 3d & dec. $226[\text { dec. } 261]^{6 \mathrm{~g}}$ & 95 \\
\hline 5 & $4-\mathrm{ClC}_{6} \mathrm{H}_{4}$ & OEt & & 3e & dec. $204[\text { dec. } 244]^{6 \mathrm{~g}}$ & 90 \\
\hline 6 & $4-\mathrm{BrC}_{6} \mathrm{H}_{4}$ & $\mathrm{Me}$ & & $3 f$ & dec. $203[\text { dec. } 244]^{6 \mathrm{~g}}$ & 50 \\
\hline 7 & $4-\mathrm{BrC}_{6} \mathrm{H}_{4}$ & OEt & & $3 g$ & dec. $205[\text { dec. } 245]^{6 \mathrm{~g}}$ & 90 \\
\hline 8 & $4-\mathrm{NO}_{2} \mathrm{C}_{6} \mathrm{H}_{4}$ & $\mathrm{Me}$ & & $3 h$ & dec. 245 [unknown] & 95 \\
\hline 9 & $4-\mathrm{NO}_{2} \mathrm{C}_{6} \mathrm{H}_{4}$ & $\mathrm{OMe}$ & & $3 \mathbf{i}$ & dec. 228 [unknown] & 95 \\
\hline 10 & $4-\mathrm{NO}_{2} \mathrm{C}_{6} \mathrm{H}_{4}$ & OEt & & $\mathbf{3 j}$ & dec. 240 [unknown] & 90 \\
\hline 11 & $4-\mathrm{NO}_{2} \mathrm{C}_{6} \mathrm{H}_{4}$ & $\mathrm{O}^{t-} \mathrm{Bu}$ & & $3 \mathbf{k}$ & dec. 240 [unknown] & 70 \\
\hline
\end{tabular}

\footnotetext{
${ }^{\mathrm{a}}$ Yields refer to isolated products.
}

As shown in Scheme 2, the proposed mechanism involves the attack of enamino ester 5, produced in situ as the reaction intermediate, onto the phenylglyoxal, and then regeneration of enamino ester 6. By nucleophilic addition of amine to the second carbonyl group of phenylglyoxal, 7 was produced, which underwent dehydration to afford the corresponding hydroxyl pyrroles 3 . To prove this statement, we carried out the reaction between enamino ester 5 with phenylglyoxal in water under US irradiation, which afforded the corresponding pyrrole $\mathbf{3 b}$ in $90 \%$ yield. Also the condensation reaction of different arylglyoxals 1 with 2 were carried out in water in the presence of hydrazine hydrate under US irradiation to furnish corresponding pyridazines $\mathbf{4}$ in good to high yields in short reaction times. 
The times of reactions (3-5 min.) were shorter than the conventional method (30-60 min.) reported by Rimaz et $\mathrm{al}^{18}$.
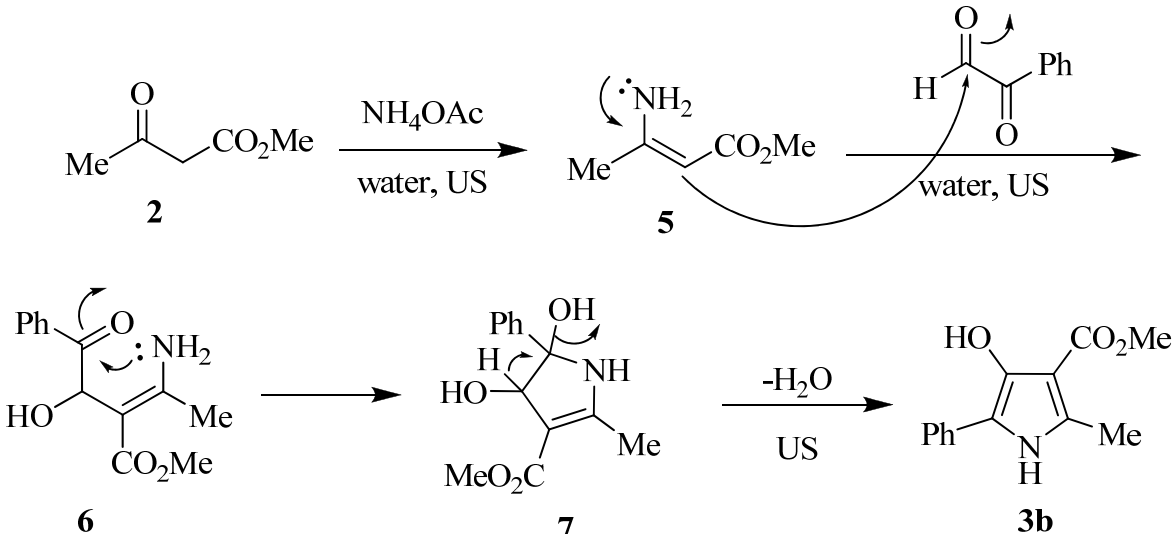

Scheme 2. The plausible reaction mechanism

The results are summarized in Table 2. Obtained products were characterized by m.p. and ${ }^{1} \mathrm{H}$ NMR and compared with reported in the literature data.

Table 2. Synthesis of pyridazines 4 (see also Scheme 1)

\begin{tabular}{|c|c|c|c|c|c|c|}
\hline Entry & Ar & $\mathbf{R}$ & Pyrrole 4 & & Mp [reported Mp] $\left({ }^{\circ} \mathrm{C}\right)$ & Yield (\%) \\
\hline 1 & $\mathrm{C}_{6} \mathrm{H}_{5}$ & $\mathrm{OMe}$ & & $4 a$ & 83-85 [unknown] & 90 \\
\hline 2 & $\mathrm{C}_{6} \mathrm{H}_{5}$ & OEt & & $4 b$ & $98-100[100-102]^{18}$ & 90 \\
\hline 3 & $\mathrm{C}_{6} \mathrm{H}_{5}$ & $\mathrm{O}^{t-} \mathrm{Bu}$ & & 4c & $96-98[98-100]^{18}$ & 93 \\
\hline 4 & $4-\mathrm{ClC}_{6} \mathrm{H}_{4}$ & $\mathrm{OMe}$ & & 4d & $116-117[118-120]^{18}$ & 75 \\
\hline 5 & $4-\mathrm{ClC}_{6} \mathrm{H}_{4}$ & OEt & & $4 e$ & $100-101[102-103]^{18}$ & 88 \\
\hline 6 & $4-\mathrm{ClC}_{6} \mathrm{H}_{4}$ & $\mathrm{O}^{t-} \mathrm{Bu}$ & & $\mathbf{4 f}$ & $80-81[82-83]^{18}$ & 80 \\
\hline 7 & $4-\mathrm{BrC}_{6} \mathrm{H}_{4}$ & $\mathrm{OMe}$ & & $4 g$ & $87-89[88-90]^{18}$ & 85 \\
\hline 8 & $4-\mathrm{BrC}_{6} \mathrm{H}_{4}$ & OEt & & $4 h$ & $97-99[99-101]^{18}$ & 75 \\
\hline 9 & $4-\mathrm{NO}_{2} \mathrm{C}_{6} \mathrm{H}_{4}$ & $\mathrm{O} t-\mathrm{Bu}$ & & $4 \mathbf{i}$ & 95-97 [unknown] & 75 \\
\hline
\end{tabular}

${ }^{\mathrm{a}}$ Yields refer to isolated products. 


\section{Conclusions}

In conclusion, we have developed a simple and facile procedure for the synthesis of 5-aryl-4hydroxy-2-methyl-1 $H$-pyrrol-3-carboxylates and 6-(4-aryl)-3-methylpyridazine-4-carboxylates involving the ultrasonic irradiation of reaction mixture in water. The advantages of this methodology are operational simplicity, high yields, short reaction times, mild reaction conditions, without using any catalysts which make it a useful and attractive process in the view of environmental and economical points.

\section{Acknowledgements}

This work was supported by University of Maragheh. Corresponding author gratefully acknowledges Mr. Biglari (IASBS) for taking NMR spectra.

\section{Experimental}

All chemicals were purchased from Merck and Fluka companies. The ${ }^{1} \mathrm{H}$ NMR and ${ }^{13} \mathrm{C}$ NMR spectra were recorded on Bruker AVANCE (400 MHz) spectrometer using $\mathrm{CDCl}_{3}$ and DMSO- $d_{6}$ as solvents. Sonication was performed in Bandeline sonoplus, GM 2200.

General procedure for synthesis of 3-hydroxy pyrroles 3

To a mixture of $\beta$-dicarbonyl compound $2(0.5 \mathrm{mmol})$ in water $(2.5 \mathrm{~mL})$, were added arylglyoxal $1(0.5 \mathrm{mmol})$ and ammonium acetate $(5 \mathrm{mmol})$. The resultant mixture was irradiated and solidified within 3-5 min, the obtained solid was then filtered. The filtrate washed with water $(3-10 \mathrm{~mL})$, and the crude material was purified by crystallization from ethanol. The products (3a-g) were known compounds, their authenticity was established by ${ }^{1} \mathrm{H}$ NMR and their melting point compared with that reported in literatures. The assignment of chemical structures for compounds $\mathbf{3 h - k}$ was confirmed by FT-IR, ${ }^{1} \mathrm{H}$ NMR, ${ }^{13} \mathrm{C}$ NMR spectral analysis and elemental analysis data.

\section{General procedure for synthesis of pyridazines 4}

To a mixture of $\beta$-dicarbonyl compound $2(0.5 \mathrm{mmol})$ in water $(2.5 \mathrm{~mL})$, were added arylglyoxal 1 $(0.5 \mathrm{mmol})$ and hydrazine hydrate $(3 \mathrm{mmol})$. The resultant mixture was irradiated and solidified within 3-5 min, the obtained solid was then filtered, the filtrate washed with water $(3-10 \mathrm{~mL})$, and the crude material was purified by crystallization from ethanol. The products (4b-h) were known compounds and their authenticity was established by ${ }^{1} \mathrm{H}$ NMR and their melting point compared with that reported in literatures. Compounds $4 \mathbf{a}$ and $4 \mathbf{i}$ were unknown and established by ${ }^{1} \mathrm{H} N M R,{ }^{13} \mathrm{C}$ NMR and elemental analysis data.

\section{Physical and Spectral Data}

The spectroscopic data for new compounds are as follows:

\section{3-Acetyl-4-hydroxy-2-methyl-5-(4-nitrophenyl)-1H-pyrrol (3h):}

A redish orange solid; Decomposed at $245^{\circ} \mathrm{C}$; FT-IR $(\mathrm{KBr}): v 3415(\mathrm{O}-\mathrm{H}), 3334(\mathrm{~N}-\mathrm{H}), 1629$

$(\mathrm{C}=\mathrm{O}), 1592(\mathrm{C}=\mathrm{C}), 1520,1326\left(\mathrm{NO}_{2}\right) \mathrm{cm}^{-1} ;{ }^{1} \mathrm{H}$ NMR $\left(400 \mathrm{MHz}, \mathrm{DMSO}-d_{6}\right): \delta_{\mathrm{H}} 2.45\left(\mathrm{~s}, 3 \mathrm{H}, \mathrm{CH}_{3}\right)$, $2.56\left(\mathrm{~s}, 3 \mathrm{H}, \mathrm{CH}_{3}\right), 7.88\left(\mathrm{~d}, J=8.8 \mathrm{~Hz}, 2 \mathrm{H}, \mathrm{CH}^{\mathrm{Ar}}\right), 8.24\left(\mathrm{~d}, J=9.2 \mathrm{~Hz}, 2 \mathrm{H}, \mathrm{CH}^{\mathrm{Ar}}\right), 10.57(\mathrm{~s}, 1 \mathrm{H}, \mathrm{OH})$, $11.67(\mathrm{~s}, 1 \mathrm{H}, \mathrm{NH}) ;{ }^{13} \mathrm{C}$ NMR $\left(100 \mathrm{MHz}, \mathrm{DMSO}-d_{6}\right): 14.9,29.4,109.7,111.7,122.6,124.9,136.9$, 138.5, 143.2, 149.3, 198.4. Anal. Calcd for $\mathrm{C}_{13} \mathrm{H}_{12} \mathrm{~N}_{2} \mathrm{O}_{4}: \mathrm{C}, 60.00 ; \mathrm{H}, 4.65 ; \mathrm{N}, 10.76 \%$. Found: $\mathrm{C}$, $60.39 ; \mathrm{H}, 4.51 ; \mathrm{N}, 10.48 \%$. 
Methyl 4-hydroxy-2-methyl-5-(4-nitrophenyl)-1H-pyrrole-3-carboxylate (3i):

A yellowish orange solid; Decomposed at $228^{\circ} \mathrm{C}$; FT-IR $(\mathrm{KBr}): v 3550(\mathrm{O}-\mathrm{H}), 3415(\mathrm{~N}-\mathrm{H}), 1670$ $(\mathrm{C}=\mathrm{O}), 1618(\mathrm{C}=\mathrm{C}), 1524,1308\left(\mathrm{NO}_{2}\right) \mathrm{cm}^{-1} ;{ }^{1} \mathrm{H}$ NMR $\left(400 \mathrm{MHz}, \mathrm{DMSO}-d_{6}\right): \delta_{\mathrm{H}} 2.45\left(\mathrm{~s}, 3 \mathrm{H}, \mathrm{CH}_{3}\right)$, $3.80\left(\mathrm{~s}, 3 \mathrm{H}, \mathrm{CH}_{3}\right), 7.91\left(\mathrm{~d}, J=9.2 \mathrm{~Hz}, 2 \mathrm{H}, \mathrm{CH}^{\mathrm{Ar}}\right), 8.23\left(\mathrm{~d}, J=8.8 \mathrm{~Hz}, 2 \mathrm{H}, \mathrm{CH}^{\mathrm{Ar}}\right), 8.86(\mathrm{~s}, 1 \mathrm{H}, \mathrm{OH})$, $11.61(\mathrm{~s}, 1 \mathrm{H}, \mathrm{NH}) ;{ }^{13} \mathrm{C}$ NMR $\left(100 \mathrm{MHz}, \mathrm{DMSO}-d_{6}\right): 13.9,51.4,101.8,110.7,122.6,124.8,136.3$, 138.8, 143.1, 147.4, 166.5. Anal. Calcd for $\mathrm{C}_{13} \mathrm{H}_{12} \mathrm{~N}_{2} \mathrm{O}_{5}$ : C, 56.52; H, 4.38; N, 10.14\%. Found: C, $56.28 ; \mathrm{H}, 4.39 ; \mathrm{N}, 10.57 \%$.

Ethyl 4-hydroxy-2-methyl-5-(4-nitrophenyl)-1H-pyrrole-3-carboxylate (3j):

A dark orange solid; Decomposed at $240{ }^{\circ} \mathrm{C}$; FT-IR $(\mathrm{KBr}):$ v $3550(\mathrm{O}-\mathrm{H}), 3412(\mathrm{~N}-\mathrm{H}), 1671$ $(\mathrm{C}=\mathrm{O}), 1595(\mathrm{C}=\mathrm{C}), 1523,1323\left(\mathrm{NO}_{2}\right) \mathrm{cm}^{-1}$; ${ }^{1} \mathrm{H}$ NMR $\left(400 \mathrm{MHz}, \mathrm{DMSO}-d_{6}\right): \delta_{\mathrm{H}} 1.32(\mathrm{t}, J=7.2 \mathrm{~Hz}$, $\left.3 \mathrm{H}, \mathrm{CH}_{3}\right), 2.45\left(\mathrm{~s}, 3 \mathrm{H}, \mathrm{CH}_{3}\right), 4.29\left(\mathrm{q}, J=7.2 \mathrm{~Hz}, 2 \mathrm{H}, \mathrm{CH}_{2}\right), 7.90\left(\mathrm{~d}, J=9.2 \mathrm{~Hz}, 2 \mathrm{H}, \mathrm{CH}^{\mathrm{Ar}}\right), 8.23(\mathrm{~d}, J$ $\left.=8.8 \mathrm{~Hz}, 2 \mathrm{H}, \mathrm{CH}^{\mathrm{Ar}}\right), 8.90(\mathrm{~s}, 1 \mathrm{H}, \mathrm{OH}), 11.61(\mathrm{~s}, 1 \mathrm{H}, \mathrm{NH}) ;{ }^{13} \mathrm{C}$ NMR (100 MHz, DMSO-d $\left.)_{6}\right): 14.0$, 14.8, 60.1, 101.8, 110.6, 122.6, 124.9, 136.1, 138.7, 143.1, 147.7, 166.4. Anal. Calcd for $\mathrm{C}_{14} \mathrm{H}_{14} \mathrm{~N}_{2} \mathrm{O}_{5}$ : C, 57.93; H, 4.86; N, 9.65\%. Found: C, 58.01; H, 4.86; N, 9.93\%.

tert-Butyl 4-hydroxy-2-methyl-5-(4-nitrophenyl)-1H-pyrrole-3-carboxylate (3k):

A pale orange solid; Decomposed at $240^{\circ} \mathrm{C}$; FT-IR (KBr): $v 3408$ (br. O-H and N-H), $1652(\mathrm{C}=\mathrm{O})$, $1595(\mathrm{C}=\mathrm{C}), 1499,1318\left(\mathrm{NO}_{2}\right) \mathrm{cm}^{-1} ;{ }^{1} \mathrm{H}$ NMR $\left(400 \mathrm{MHz}, \mathrm{DMSO}-d_{6}\right): \delta_{\mathrm{H}} 1.56\left(\mathrm{~s}, 9 \mathrm{H}, \mathrm{CH}_{3}\right), 2.43(\mathrm{~s}$, $\left.3 \mathrm{H}, \mathrm{CH}_{3}\right), 7.89\left(\mathrm{~d}, J=9.2 \mathrm{~Hz}, 2 \mathrm{H}, \mathrm{CH}^{\mathrm{Ar}}\right), 8.23\left(\mathrm{~d}, J=8.8 \mathrm{~Hz}, 2 \mathrm{H}, \mathrm{CH}^{\mathrm{Ar}}\right), 8.97(\mathrm{~s}, 1 \mathrm{H}, \mathrm{OH}), 11.56(\mathrm{~s}$, $1 \mathrm{H}, \mathrm{NH}) ;{ }^{13} \mathrm{C}$ NMR $\left(100 \mathrm{MHz}, \mathrm{DMSO}-d_{6}\right): 14.1,27.8,81.3,102.5,110.2,122.5,124.9,135.8,138.7$, 143.0, 148.1, 166.7. Anal. Calcd for $\mathrm{C}_{16} \mathrm{H}_{18} \mathrm{~N}_{2} \mathrm{O}_{5}$ : C, 60.37; H, 5.70; N, 8.80\%. Found: C, 60.38; H, $5.69 ; \mathrm{N}, 9.10 \%$.

Methyl 3-methyl-6-phenylpyridazine-4-carboxylate (4a):

A dark yellow solid; mp 83-85 ${ }^{\circ} \mathrm{C}$; ${ }^{1} \mathrm{H}$ NMR $\left(400 \mathrm{MHz}, \mathrm{CDCl}_{3}\right): \delta_{\mathrm{H}} 3.07\left(\mathrm{~s}, 3 \mathrm{H}, \mathrm{CH}_{3}\right), 4.05(\mathrm{~s}, 3 \mathrm{H}$, $\left.\mathrm{OCH}_{3}\right), 7.56-7.59\left(\mathrm{~m}, 3 \mathrm{H}, \mathrm{CH}^{\mathrm{Ph}}\right), 8.14-8.17\left(\mathrm{~m}, 2 \mathrm{H}, \mathrm{CH}^{\mathrm{Ph}}\right), 8.29\left(\mathrm{~s}, 1 \mathrm{H}, \mathrm{CH}^{\text {Pyridazine }}\right) ;{ }^{13} \mathrm{C} \mathrm{NMR}(100$ $\mathrm{MHz}, \mathrm{CDCl}_{3}$ ): 22.0, 53.1, 123.8, 126.9, 128.4, 129.1, 130.3, 135.5, 156.8, 158.2, 166.2. Anal. Calcd for $\mathrm{C}_{13} \mathrm{H}_{12} \mathrm{~N}_{2} \mathrm{O}_{2}$ : C, 68.41; H, 5.30; N, 12.27\%. Found: C, 68.47; H, 5.31; N, 12.00\%.

tert-Butyl 3-methyl-6-(4-nitrophenyl)pyridazine-4-carboxylate (4i):

A dark brown solid; mp 95-97 ${ }^{\circ} \mathrm{C}$; ${ }^{1} \mathrm{H}$ NMR $\left(400 \mathrm{MHz}, \mathrm{CDCl}_{3}\right): \delta_{\mathrm{H}} 1.69\left(\mathrm{~s}, 9 \mathrm{H}, \mathrm{CH}_{3}\right), 3.06(\mathrm{~s}, 3 \mathrm{H}$, $\left.\mathrm{CH}_{3}\right), 8.24\left(\mathrm{~s}, 1 \mathrm{H}, \mathrm{CH}^{\text {Pyridazine }}\right) 8.34\left(\mathrm{~d}, J=8.8 \mathrm{~Hz}, 2 \mathrm{H}, \mathrm{CH}^{\mathrm{Ar}}\right), 8.43\left(\mathrm{~d}, J=9.2 \mathrm{~Hz}, 2 \mathrm{H}, \mathrm{CH}^{\mathrm{Ar}}\right) ;{ }^{13} \mathrm{C}$ NMR (100 MHz, $\left.\mathrm{CDCl}_{3}\right): 22.2,28.2,84.4,124.0,124.3,127.8,130.7,141.6,148.9,156.4,158.0$, 164.2. Anal. Calcd for $\mathrm{C}_{16} \mathrm{H}_{17} \mathrm{~N}_{3} \mathrm{O}_{4}$ : C, 60.94; H, 5.43; N, 13.33\%. Found: C, 61.01; H, 5.38; N, $13.00 \%$.

\section{References}

1. (a) Eftekhari-Sis B., Zirak M., and Akbari A. (2013) Arylglyoxals in synthesis of heterocyclic compounds. Chem. Rev., doi: 10.1021/cr300176g. (b) Akbari A. (2012) Phenylglyoxal. Synlett, 23, 951-952.

2. Jones R. A. (1992) Pyrroles, Part II, Wiley, New York.

3. Gilchrist T. L. (1999) Synthesis of aromatic heterocycles. J. Chem. Soc., Perkin Trans. 1, 28492866.

4. (a) Thompson R. B. (2001) Foundations for blockbuster drugs in federally sponsored research. FASEB J., 15, 1671-1676. (b) Mach R. H., Huang Y., Freeman R. A., Wu L., Blair S., and Luedtke R. R. (2003) Synthesis of 2-(5-bromo-2,3-dimethoxyphenyl)-5-(aminomethyl)-1H-pyrrole analogues and their binding affinities for dopamine $\mathrm{D}_{2}, \mathrm{D}_{3}$, and $\mathrm{D}_{4}$ receptors. Bioorg. Med. Chem., 11, 225-233. (c) Bleicher K. H., Wüthrich Y., Adam G., Hoffmann T., and Sleight A. J. (2002) Parallel solution- and solid-phase synthesis of spiropyrrolo-pyrroles as novel neurokinin receptor 
ligands. Bioorg. Med. Chem. Lett., 12, 3073-3076. (d) Borthwick A. D., Crame A. J., Ertl, P. F., Exall, A. M., Haley T. M., Hart G. J., Mason A. M., Pennell A. M. K., Singh O. M. P., Weingarten G. G., and Woolven J. M. (2002) Design and synthesis of pyrrolidine-5,5-trans-lactams (5oxohexahydropyrrolo[3,2-b]pyrroles) as novel mechanism-based inhibitors of human cytomegalovirus protease. 2. potency and chirality. J. Med. Chem., 45, 1-18. (e) Lee H., Lee J., Lee S., Shin Y., Jung W. H., Kim J. -H., Park K., Kim K., Cho H. S., Ro S. Lee S. Jeong S., Choi T., Chung H. -H., and Koh J. S. (2001) A novel class of highly potent, selective, and non-peptidic inhibitor of ras farnesyltransferase (FTase). Bioorg. Med. Chem. Lett., 11, 3069-3072. (f) Brower J. O., Lightner D. A., and McDonagh A. F. (2001) Aromatic congeners of bilirubin: synthesis, stereochemistry, glucuronidation and hepatic transport. Tetrahedron, 57, 7813-7827. (g) Seki M., and Mori K. (2001) The absolute configuration of axinellamine A, a pyrrole alkaloid of the marine sponge Axinella sp., was determined as $R$ by synthesizing its (S)-isomer. Eur. J. Org. Chem., 503506.

5. (a) Higgins S. A. (1997) Conjugated polymers incorporating pendant functional groups-synthesis and characterization. Chem. Soc. Rev., 26, 247-257. (b) Lee C. -F., Yang L. -M., Hwu T. -Y., Feng A. -S., Tseng J. -C., and Luh T. -Y. (2000) One-pot synthesis of substituted furans and pyrroles from propargylic dithioacetals. new annulation route to highly photoluminescent oligoaryls. J. Am. Chem. Soc., 122, 4992-4993. (c) Ogawa K., and Rasmussen R. C. (2003) A simple and efficient route to $N$-functionalized dithieno[3,2-b:2', $\left.3^{\prime}-d\right]$ pyrroles: fused-ring building blocks for new conjugated polymeric systems. J. Org. Chem., 68, 2921-2928. (d) Tietze L. F., Kettschau G., Heuschert U., and Nordmann G. (2001) Highly efficient synthesis of linear pyrrole oligomers by twofold Heck reactions. Chem. Eur. J., 7, 368-373.

6. (a) Trofimov B. A., Sobenina L. N., Demenev A. P., and Mikhaleva A. I. (2004) C-Vinylpyrroles as pyrrole building blocks. Chem. Rev., 104, 2481-2506. (b) Liu J. -H., Yang Q. -C., Mak T. C. W., and Wong H. N. C. (2000) Highly regioselective synthesis of 2,3,4-trisubstituted $1 H$-pyrroles: a formal total synthesis of Lukianol A. J. Org. Chem., 65, 3587-3595. (c) Fürstner A., and Weintritt H. (1998) Total synthesis of roseophilin. J. Am. Chem. Soc., 120, 2817-2825. (d) Kim J. T., Kel'in A. V., and Gevorgyan V. (2003) 1,2-Migration of the thio group in allenyl sulfides: efficient synthesis of 3-thio-substituted furans and pyrroles. Angew. Chem., Int. Ed., 42, 98-101. (e) Bullington J. L., Wolff R. R., and Jackson P. E. (2002) Regioselective preparation of 2substituted 3,4-diaryl pyrroles: a concise total synthesis of Ningalin B. J. Org. Chem., 67, 94399442. (f) Attanasi O. A., De Crescentini L., Favi G., Filippone P., Mantellini F., and Santeusanio S. (2002) Straightforward entry into 5-hydroxy-1-aminopyrrolines and the corresponding pyrroles from 1,2-diaza-1,3-butadienes. J. Org. Chem., 67, 8178-8181. (g) Khalili B., Jajarmi P., EftekhariSis B., and Hashemi M. M. (2008) Novel one-pot, three-component synthesis of new 2-alkyl-5aryl-(1H)-pyrrole-4-ol in water. J. Org. Chem., 73, 2090-2095. (h) San Feliciano A., Caballero E., Pereira J. A. P., and Puebla P. (1989) Pyrrole derivatives from $\alpha$-ketoaldehydes. Tetrahedron 45, 6553-6562.

7. Benson S. C., Palabrica C. A., and Snyder J. K. (1987) Indole as a dienophile in inverse electron demand Diels-Alder reactions. 5H-Pyridazino[4,5-b]indoles as cycloadducts with 3,6dicarbomethoxy-1,2,4,5-tetrazine. J. Org. Chem., 52, 4610-4614.

8. (a) Contreras J. -M., Rival Y. M., Chayer S., Bourguignon J. -J., and Wermuth C. G. (1999) Aminopyridazines as acetylcholinesterase inhibitors. J. Med. Chem., 42, 730-741. (b) Wermuth C. -G. (1998) Search for new lead compounds: The example of the chemical and pharmacological dissection of aminopyridazines. J. Heterocycl. Chem., 35, 1091-1100. (c) Gelain A. (2005) Pyridazine derivatives as novel acyl-coa:cholesterol acyltransferase (acat) inhibitors. $J$. Heterocycl. Chem., 42, 395-400.

9. (a) Groziak M. P. (2005) Six-membered ring systems: diazines and benzo derivatives, in: Gribble G. W., and Joule J. A. (Eds.), Progress in Heterocyclic Chemistry. Elsevier, Amsterdam, Vol. 16, pp. 347-384 (b) Groziak M. P. (2005) Six-membered ring systems: diazines and benzo derivatives, in: Gribble G. W., and Joule J. A. (Eds.), Progress in Heterocyclic Chemistry. Elsevier, 
Amsterdam, Vol. 17, pp. 304-336. (c) Naud S., Pipelier M., Viault G., Adjou A., Huet F., Legoupy S., Aubertin A. -M., Evain M., and Dubreuil D. (2007) Synthesis of polyhydroxylated pyranopyrrole derivatives from carbohydrate precursors. Eur. J. Org. Chem., 3296-3310.

10. (a) Sauer J., Heldmann D. K., Hetzenegger J., Krauthan J., Sichert H., and Schuster J. (1998) 1,2,4,5-Tetrazine: synthesis and reactivity in [4+2] cycloadditions. Eur. J. Org. Chem., 2885-2896. (b) Yu Z. -X., Dang Q., and Wu Y. -D. (2001) Aromatic dienophiles. 1. A theoretical study of an inverse-electron demand Diels-Alder reaction between 2-aminopyrrole and 1,3,5-triazine. J. Org. Chem., 66, 6029-6036.

11. (a) Özer G., Saraçoğlu N., and Balci M. (2003) Synthesis and chemistry of unusual bicyclic endoperoxides containing the pyridazine ring. J. Org. Chem., 68, 7009-7015. (b) Hamasaki A., Ducray R., and Boger D. L. (2006) Two novel 1,2,4,5-tetrazines that participate in inverse electron demand Diels-Alder reactions with an unexpected regioselectivity. J. Org. Chem., 71, 185-193. (c) Attanasi O. A., Favi G., Filippone P., Perrulli F. R., and Santeusanio S. (2009) A novel and convenient protocol for synthesis of pyridazines. Org. Lett. 11, 309-312. (d) Hieda M., Omura K., and Yurugi S. (1972) Studies on the syntheses of $N$-heterocyclic compounds. XI. Syntheses of 3phenyl-pyridazino[4,5-c]-and 5-phenyl-pyridazino-[4,5- $d$ ]pyridazine derivatives. Yakugaku Zasshi 92, 1327-1332.

12. (a) Mason T. J., and Peters D. (2002) Practical Sonochemistry. Second ed., Ellis Horwood, London. (b) Luche J. L. (1998) Synthetic Organic Sonochemistry. Plenum, New York. (c) Mason T. J., and Lorimer J. P. (1988) Sonochemistry: Theory, Applications and Uses of Ultrasound in Chemistry. Ellis Horwood, Chichester.

13. Mason T. J. (2007) Sonochemistry and the environment-providing a "green" link between chemistry, physics and engineering. Ultrason. Sonochem., 14, 476-483.

14. Mason T. J. (1991) Practical Sonochemistry. Ellis Horwood, 18.

15. (a) Satyanarayana V. S. V., and Sivakumar A. (2011) Ultrasound-assisted synthesis of 2,5dimethyl-N-substituted pyrroles catalyzed by uranyl nitrate hexahydrate. Ultrason. Sonochem., 18, 917-922. (b) Zhang Z. -H., Li J. -J., and Li T. -S. (2008) Ultrasound-assisted synthesis of pyrroles catalyzed by zirconium chloride under solvent-free conditions. Ultrason. Sonochem., 15, 673-676. (c) Mantu D., Moldoveanu C., Nicolescu A., Deleanu C., and Mangalagiu I. I. (2009) A facile synthesis of pyridazinone derivatives under ultrasonic irradiation. Ultrason. Sonochem., $16,452-454$.

16. (a) Eftekhari-Sis B., Abdollahifar A., Hashemi M. M., and Zirak M. (2006) Stereoselective synthesis of $\beta$-amino ketones via direct Mannich-type reactions, catalyzed with $\mathrm{ZrOCl}_{2} \cdot 8 \mathrm{H}_{2} \mathrm{O}$ under solvent-free conditions. Eur. J. Org. Chem., 5152-5157. (b) Eftekhari-Sis B., Zirak M., Akbari A., and Hashemi M. M. (2010) Synthesis of new 2-aryl-4-chloro-3-hydroxy-1H-indole5,7-dicarbaldehydes via Vilsmeier-Haack reaction. J. Heterocycl. Chem., 47, 463-467.

17. Riley H. A., and Gray A. R. (1943) Organic Syntheses. Wiley \& Sons, New York, NY; Collect. Vol. II, p. 509.

18. Rimaz M., and Khalafy J. (2010) Arkivoc, ii, 110-117. 